\title{
PENGEMBANGAN MODUL BERBASIS SETS (SCIENCE, ENVIRONMENT, TECHNOLOGY, SOCIETY) TERINTEGRASI NILAI ISLAM DI SMAI SURABAYA PADA MATERI IKATAN KIMIA
}

\author{
Siti Zainatur Rahmah \\ Universitas Sebelas Maret \\ E-mail: zainaturrahma@ student.uns.ac.id \\ Sri Mulyani \\ Universitas Sebelas Maret \\ Moh. Masyikuri \\ Universitas Sebelas Maret
}

\begin{abstract}
Abstrak
Tujuan penelitian ini adalah: (1) Pengembangan produk modul kimia berbasis SETS terintegrasi nilai islam pada materi ikatan kimia, (2) Mengetahui kelayakan modul kimia berbasis SETS terintegrasi nilai islam, (3) Mengetahui keefektifan keterterapan modul kimia berbasis SETS terintegrasi nilai islam. Produk yang dikembangkan dalam penelitian ini adalah modul kimia berbasis SETS terintegrasi nilai islam pada materi ikatan kimia. Spesifikasi modul kimia berbentuk media cetak sebagai implementasi kurikulum 2013 berbasis kompetensi. Subjek dalam penelitian ini adalah siswa kelas X SMA Yapita, SMA HU, SMA Muhammadiyah 7, dan SMA IT Al-Uswah, di Surabaya . Sampel terdiri dari satu kelas pengguna modul dan satu kelas kontrol yang dipilih secara teknik random sampling. Uji reliabilitas menggunakan rumus Kuder Richardson. Sedangkan untuk validitas isi, digunakan formula Aiken. Teknik analisis data yang digunakan ialah deskriptif kualitatif. Kesimpulan dari penelitian ini yaitu; Pertama, Pengembangan modul kimia berbasis SETS terintegrasi nilai islam pada materi ikatan kimia dilakukan dengan menggunakan langkah pengembangan yang kemukakan oleh Borg \& Gall (1983) sampai pada tahap ke sembilan. Kedua, Pengembangan modul kimia berbasis SETS terintegrasi nilai islam dapat dikatakan "sangat baik" ditinjau dari aspek materi $85,9 \%$, penyajian $85,8 \%$, bahasa $85,4 \%$ dan kegrafisan $86,03 \%$. Ketiga, Pengembangan modul kimia berbasis SETS terintegrasi nilai islam yang dikembangkan efektif digunakan untuk meningkatkan hasil belajar para siswa. Sehingga dapat disimpulkan bahwa hasil belajar menggunakan modul kimia berbasis SETS terintegrasi nilai islam lebih baik dari pembelajaran konvensional.
\end{abstract}

Kata Kunci: modul kimia, SETS, nilai islam, ikatan kimia.

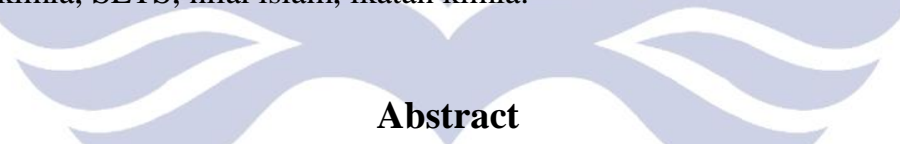

The goals of this study are: (1) Development of SETS based chemical module integrated to Islamic value on chemical bonding topic, (2) Determine the feasibility of SETS based chemical module integrated to Islamic value, (3) Determine the effectiveness of SETS based chemical module integrated to Islamic value. Product developed in this study was SETS based chemical module integrated to Islamic value on chemical bonding topic. Specifications is print media shaped as a competency based on curriculum implementation in 2013. Subjects in this study were class X high scool in Surabaya: Yapita, Hidayatul Ummah, Muhammadiyah 7, and IT Al-Uswah. The sample consists of one class of user modules and one control class were selected by random sampling technique. Reliability testing used Kuder Richardson formula. As for the validity of the content used the formula Aiken. Data analysis technique used descriptive qualitative. The conclusion of this study are; First, the development of SETS based chemical module integrated to Islamic value on chemical bonding topic is done by using Borg and Gall (1983) method up to the stage nine. Second, the development of SETS based chemical module integrated to Islamic value is qualified "very good" in terms of the material aspect of $85.9 \%$, presenting $85.8 \%$, language $85.4 \%$, and graphic $86.03 \%$. Third, development of SETS based chemical module integrated to Islamic value is effectively used to improve student outcomes. It can be concluded that the result of learning using a SETS based chemical module integrated to Islamic value is better than conventional learning.

Keywords: chemical module, SETS, islamic value, chemical bonding. 


\section{PENDAHULUAN}

Dalam rangka menuju "Generasi Emas Indonesia 2045" pembelajaran di sekolah dianggap sebagai tempat terbaik untuk mempersiapkan agen perubahan bangsa yang akan membawa sejahtera kepada orang lain. Guru tidak lagi menjadi tempat untuk mentransfer pengetahuan saja, tetapi juga tempat untuk membentuk sikap, perilaku, karakter, dan kepemimpinan (Rokhmana, et al., 2014). Hal ini sejalan dengan arahan yang diberikan pada kurikulum 2013.

Kurikulum 2013 memberikan arahan bahwa pembelajaran sains harus bertumpu pada keaktifan siswa dan mereka harus mendapatkan pengalaman nyata dalam proses pembejarannya. setiap pembelajaran hendaknya dapat membentuk moral dan kepribadian siswa seperti jujur, bertanggung jawab, disiplin, dan meningkatkan ketakwaan mereka terhadap Allah SWT (Kemendiknas, 2013). Begitu pula seharusnya bahan ajar yang digunakan hendaknya dapat memuat arahan tersebut sehingga mampu membantu siswa belajar mandiri dan mengembangkan diri (Saputro, 2008).

Beberapa hasil obervasi yang dilakukan pada SMA yang telah menerapkan kurikulum 2013 di SMA IT Al-Uswah, SMA Muhammadiyah 7, dan SMA Yapita, di Surabaya didapatkan beberapa permasalahan yaitu guru dalam proses pembelajaran masih menggunakan bahan ajar berupa buku paket dipasaran yang belum berfungsi sebagaimana idealnya yaitu memberdayakan siswa untuk berpikir kiritis, kreatif, dan memingkatkan nilai keimanan mereka. Hal ini tidak sesuai dengan dengan pembelajaran pada kurikulum 2013 yaitu melakukan pembelajaran yang bermakna. Selain itu, berdasarkan hasil wawancara dengan siswa tanggapan mereka terhadap bahan ajar yang ada tidak menarik, tampilan yang monoton, dan belum memuat pembelajaran moral siswa.

Pencapaian hasil belajar pada materi ikatan kimia yang masih rendah memiliki beberapa faktor yaitu tingkat kesulitan materi yang cukup tinggi pada kelas $\mathrm{X}$ semester ganjil jika dibandingkan dengan materi yang lain. Berdasarkan hasil wawancara terhadap guru mata pelajaran kimia tidak semua guru membuat silabus dan RPP yang sesuai dengan kondisi real kebutuhan sekolah. RPP yang dibuat pun sebagian besar hanya untuk kebutuhan administrasi bukan sebagai acuan utama dalam proses pembelajaran.

SMA berbasis islam merupakan sekolah yang memiliki karakteristik berbeda dengan SMA umum. Pembelajaran lebih ditekankan pada nuansa agama islam, sehingga siswa yang masuk di sekolah ini pun sebagian besar memiliki motivasi untuk mendalami agama islam disamping menguasi pengetahuan umum lainnya. Hal ini belum dapat berjalan dengan maksimal di MA dan SMA islam, hal tersebut dikarenakan belum terintegrasinya antara pembelajaran umum khususnya IPA (kimia) terhadap nilai-nilai moral yang terdapat dalam ajaran islam. Hal ini juga yang menyebabkan rendahnya ketertarikan siswa terhadap mata pelajaran kimia.

Pembelajaran dengan sistem pengajaran islam terbukti telah mampu meningkatkan karakter siswa, salah satunya hasil penelitian Ismail M., et al. (2013) yang mampu meningkatkan kedisiplinan siswa. Hamidi F, et al.(2010) secara lebih luas membuktikan pembelajaran yang berbasis Al-Qur'an dapat meningkatkan kesehatan mental siswa sehingga dengan ini diharapkan memicu prestasi mereka. Al-Quran sebagai pedoman utama ummat islam tidak hanya memuat aturan hidup manusia namun juga banyak mengandung informasi ilmu pengetahuan alam. Pembelajaran kimia dalam Al-Qur'an tidak hanya sebagai bukti terhadap keesaan Allah SWT, namun juga memuat pembelajran akhlak yang baik dalam kehidupan sehari-hari seperti kaitannya dalam materi ikatan kimia.

Pendekatan pembelajaran yang sesuai dengan kurikulum 2013 salah satunya adalah SETS (Science, Environment, Technology, Society). SETS merupakan suatu pendekatan terpadu yang melibatkan unsur sains, teknologi, dan masyarakat. Pendekatan ini bertujuan membantu siswa mengetahui sains, perkembangannya, pengruh lingkungan, teknologi, dan masyarakat secara timbal balik (Binadja, 2005). Berdasarkan peneletian terdahulu yang dilakukan Nugraha, et al.(2013), Setiyono (2011) dan Rahman O.A. (2013) bahwa pembelajaran berbasis SETS mampu meningkatkan kemampuan berfikir kritis, kretifitas dan hasil belajar siswa. Hal ini menunjukkan bahwa SETS memiliki efektifitas yang tinggi untuk digunakan dalam pembelajaran.

Pentingnya penyususnan modul berbasis SETS terintegrasi ini juga didukung oleh hasil analisis buku panduan pembelajaran kimia yang digunakan di SMA IT Al-Uswah terhadap karakteristik nilai SETS dengan persentase $38,8 \%$ sedangkan terhadap nilai islam sebesar $25 \%$ prosentase ini termasuk dalam kategori tidak baik. Berdasarkan latar belakang tersebut maka diperlukan pengembangan penelitian tentang modul pembelajaran SETS yang mengintegrasikan pembelajaran kimia dengan nilai-nilai moral dalam ajaran islam sehingga dapat memberikan pembelajaran yang lebih bermakna dan meningkatkan karakter siswa.

\section{METODE}

Penelitian ini dilaksanakan di di SMA IT AlUswah, SMA Muhammadiyah 7, SMA Yapita, dan SMA Hidayatul Ummah, kota Surabaya, Provinsi Jawa Timur, Indonesia. Penelitian dan pengembangan dilaksanakan pada semester gasal pada tahun 2015/ 2016, yang secara garis besar dibagi menjadi tiga tahap, yaitu: Pertama, Tahap persiapan, meliputi: permohonan ijin penelitian, survei ke sekolah yang digunakan untuk penelitian, permohonan pembimbing, pengajuan judul penelitian, pembuatan proposal, dan penyusunan instrumen penelitian. Kedua, Tahap penelitian dan pengembangan, meliputi: pengembangan modul Kimia melibatkan para pakar untuk menilai dan memberi masukan dan diujicobakan di semua kegiatan yang berlangsung di lapangan, uji coba instrumen, dan pelaksanaan pengambilan data. Ketiga, Tahap penyelesaian, meliputi: analisis data, pembahasan dan penyusunan laporan penelitian. 
Penelitian ini adalah penelitian pengembangan (Research and development) atau disebut dengan penelitian R\&D. Metode ini merupakan metode penelitian yang digunakan untuk menghasilkan produk tertentu dan menguji keefektifan produk tersebut. Langkah pengembangan mengacu pada Borg \& Gall, yang memiliki 10 langkah sebagai berikut: (1) melakukan penelitian dan pengumpulan informasi (Research and information collection) termasuk kajian literatur, observasi kelas, dan membuat kerangka kerja penelitian; (2) melakukan perencanaan (Planning) termasuk tujuan perencanaan, menentukan urutan untuk penelitian; (3) mengembangkan bentuk awal produk (Develop preliminary form of product); (4) melakukan uji lapangan awal/ uji coba kelompok kecil (Preliminary field testing); (5) melakukan revisi terhadap produk utama (Main product revision); (6) melakukan uji lapangan utama (Main field testing); (7) melakukan revisi terhadap produk utama (Operational product revision); (8) melakukan uji lapangan operasional (Operational field testing); (9) melakukan revisi terhadap produk akhir (Final product revision); (10) mendeseminasikan dan mengimplementasikan produk (Dissemination and implememtasion), pada tahap ke sepuluh tidak dilakukan karena membutuhkan waktu yang lama dan tujuan dari penelitian ini sampai pada penyempurnaan produk akhir.

Langkah-langkah penelitian dan pengembangan modul kimia berbasis inkuiri terbimbing yang disertai ayat-ayat Al-qur'an dan Hadits diatas secara rinci dapat dijelaskan sebagai berikut: Pertama, Analisis studi Literatur. Pada tahap penelitian dan pengumpulan informasi dilakukan melalui studi literatur dan studi lapangan. Studi literatur digunakan untuk mengumpulkan berbagai informasi terkait pengembangan modul berbasis SETS terintegrasi nilai islam melalui kajian pustaka dan hasil penelitian yang relevan. Kedua, Analisis studi Lapangan. Studi lapangan dilakukan untuk memperoleh informasi tentang kebutuhan-kebutuhan yang diperlukan dalam menunjang kegiatan pembelajaran kimia terutama pada aspek guru, siswa, bahan ajar, metode dan sarana pembelajaran lainnya.

Subyek dalam uji efektivitas adalah siswa kelas X SMA IT Al-Uswah Surabaya. Sampel yang digunakan untuk uji berjumlah dua kelas. Sampel terdiri dari satu kelas pengguna dan satu kela kontrol yang dipilih secara teknik random sampling dengan didahului uji prasyarat pengambilan sampel (uji keseimbangan). Jumlah sampel telah sesuai dengan jumlah sampel uji lapangan menurut Suparman (2012) yaitu paling tidak sebanyak 15-30 orang. Data yang diperoleh dari uji efektivitas berupa data kualitatif dan data kuantitatif. Data kualitatif terdiri dari data keterlaksanaan sintaks implementasi modul berbasis SETS terintegrasi nilai islam serta tanggapan guru dan siswa. Data kualitatif terdiri dari data hasil belajar siswa.

Untuk bisa mengetahui apakah validitas isi memenuhi syarat atau tidak, digunakan formula Aiken. Formula ini sebagai alat ukur yang digunakan untuk mengetahui validitas isi secara keseluruhan. Pada penelitian ini, jumlah penilai (reter) sebanyak tujuh (6) orang panelis untuk memeriksa kecocokan antara indikator dengan butir-butir instrumen, dalam bentuk menilai dari skala penilaian 1 sampai 4 dari masingmasing dari indikator. Untuk mencari reliabilitas soal bentuk obyektif digunakan rumus Kuder Richardson, yaitu KR-21.

Teknik analisis data yang digunakan dalam penelitian ini ialah dengan menganalisis data secara deskriptif kualitatif. Analisis digunakan untuk menyajikan informasi tentang data penelitian yang meliputi analisis kebutuhan, kelayakan produk dari para validator, respon siswa dan guru, kegiatan pembelajaran, serta data tes hasil belajar (post test), keterampilan, dan sikap siswa. Analisis data secara deskriptif kualitatif yaitu menguraikan serta menginterpretasikan data yang diperoleh dilapangan dari nara sumber. Analisis data ini didasarkan pada kemampuan nalar dalam menghubungkan fakta, data dan informasi sehingga diharapkan muncul gambaran yang dapat mengungkapkan permasalahan peneliti.

\section{HASIL DAN PEMBAHASAN}

\section{Pengembangan Produk Modul Kimia Berbasis SETS terintegrasi Nilai Islam}

Pengembangan produk modul kimia berbasis SETS terintegrasi nilai islam pada materi ikatan kimia dikembangkan sesuai dengan prosedur pengembangan Borg dan Gall (1983) yang dimodifikasi menjadi sembilan tahapan. Analisis kebutuhan merupakan bagian terpenting sebelum dilakukannya pengembangan modul. Tahapan pertama melakukan penelitian dan pengumpulan informasi yang didalam terdiri dari analisis studi literatur, studi lapangan dan studi kurikulum.

Hasil observasi berupa angket kebutuhan guru dan wawancara didapatkan bahwa guru memerlukan suatu bahan ajar dan metode yang tepat sehingga dapat membantu proses pembelajaran agar siswa lebih mandiri, dan kreatif dalam berfikir. Modul merupakan solusi karena modul merupakan salah satu bahan ajar yang dikemas secara utuh dan sistematis, yang didalamnya memuat tentang pengalaman belajar yang terencana dan didesain agar siswa dapat menggunakannya secara mandiri (Depdiknas, 2008; Andi Prastowo, 2010). Pendekatan dalam modul tersebut adalah SETS, pemilihan pendekatan tersebut mengacu pada hasil penelitian yang menunjukkan bahwa pembelajaran SETS dapat meningkatkan pemahaman sains, produktivitas dalam berfikir kreatif, siswa lebih terampil dalam memperoleh dan menganalisis informasi, dan dapat meningkatkan prestasi belajar (Nugraha, 2013; Setiyono, 2011).

Berdasarkan hasil wawancara guru, materi yang sulit untuk dipahami oleh siswa pada semester gasal adalah ikatan kimia. Hal ini disebabkan dalam pembentukan ikatan kimia dibutuhkan pemahaman konsep yang tepat. Pemilihan pendekatan SETS terintegrasi nilai islam ini dapat mempermudah memahami konsep materi karena dihubungkan dalam kehidupan sehari-hari, selain itu siswa yang memiliki kemampuan rendah juga dapat berpartisipasi aktif dalam 
pembelajaran. Hal ini sejalan dengan hasil penelitian Rohman (2013) yang menunjukkan bahwa pembelajaran berbasis SETS mampu meningkatkan berfikir keritis, kretivitas, dan hasil belajar siswa.

Selanjutnya, berangkat dari analisis studi kurikulum baik pada kompetensi inti (KI) dan Kompetensi dasar (KD) menunjukkan bahwa didalam pelaksanaan pembelajaran masih menggunakan pendekatan yang bersifat teacher centered padahal didalam kurikulum 2013 diharapkan siswa lebih berpartisipasi aktif. Selain lebih ditekankan pada pendekatan student centered, pada Kompetensi Dasar (KD) 1.1 dan Kompetensi Dasar (KD) 1.2 diharapkan siswa lebih menyadari akan kebesaran, kebenaran dan kekuasaan Tuhan YME. Selain itu, siswa juga diharapkan agar dapat lebih menyadari keteraturan dan keterkaitan antara ilmu sains dan ayat-ayat Al-Qur'an dan Hadits sehingga diharapkan dapat meningkatkan keimanan (Saputro, 2008). Menurut Moh Roqib (2011) bukti dari keimanan adalah berbuat baik terhadap sesama (berakhlak mulia), hal ini sinergis dengan tujuan pendidikan nasional yaitu berkembangnya potensi peserta didik agar menjadi manusia yang beriman dan bertakwa kepada Tuhan Yang Maha Esa, berakhlak mulia, sehat, berilmu, cakap, kreatif, mandiri, dan menjadi warga negara yang demokratis serta bertanggung jawab.

Produk modul kimia berbasis inkuiri terbimbing pada materi ikatan kimia dikembangkan beradasarkan karakteristik pembelajaran SETS. Karakteristik SETS meliputi 1) Kontekstual; 2) Aplikasi teknologi; 3) Dampak positif dan negatif teknologi; 4) Menghubungkan antar unsur SETS; 5) Solusi dari dampak negatif. 6) Konstruktivis. Sedangkan dari sisi pengembangan modul yang berdasarkan nilai islam mencakup beberapa nilai yaitu 1) Habblun minallah (bersyukur dan ketauhidan); 2) Hablun minannas (saling tolong-menolong); 3) Hablun minannafsi (Percaya diri dan kejujuran); 4) Hablun minalalam (kepedulian terhadap lingkungan).

Modul SETS terintegrasi nilai islam hasil pengembangan memiliki sub bagian yaitu: 1) Halaman awal modul yang terdiri dari: halaman francis, kata pengantar, karakteristik modul, daftar isi, peta konsep, dan kompetensi dasar; 2) Bagian 1 : Al-kemia dalam islam yang terdiri dari dua sub bab yaitu kejayaan ilmuan kimia muslim dan apa manfaat belajar kimia, bagian ini bertujuan untuk memberi wawasan dan motivasi kepada siswa untuk meneladani ilmuan muslim; 3) Bagian 2: kegiatan pembelajaran yang berisi uraian materi yang terdidi dari tiga bagian (perjodohan antar unsur kimia, iktan kimia "bersama kita bisa", dan Ikatan kimia yang istimewa), kegiatan belajar ke-1 sampai ke-3 memiliki urutan: Hubungan materi dengan nilai islam, uraian materi terkait, Aplication (aplikasi teknologi yang berhubungan dengan materi), Let's Connecting (menganalisis dan menghubungkan teknologi terkait melalui bagan SETS), Let's Tink (Mengambil hikmah yang didapat dari materi yang berhubungan dengan nilai islam untuk diterapkan dalam kehidupan sehari-hari), Exercise (latihan soal untuk meningkatkan pemahaman siswa), dan Summary (rangkuman dari materi); 4) Bagian
3: penilaian yang berisi evaluasi dan tugas; 5) Penutup: glosarium dan daftar pustaka.

\section{Kelayakan Modul Kimia Berbasis SETS terintegrasi Nilai Islam pada Materi Ikatan Kimia}

Kelayakan Modul Kimia Berbasis SETS terintegrasi nilai islam diuji melalui tahap validasi ahli, penilaian praktisi pendidikan, dan siswa sebagai kelompok uji skala kecil, uji coba lapangan, dan uji pelaksanaan lapangan. Hasil validasi 2 ahli dan 4 praktisi pendidikan menunjukkan bahwa modul sudah sesuai dengan yang dikembangkan dengan hasil kriteria memiliki kualitas sangat baik. Hal ini berdasarkan penilaian para ahli terhadap 4 aspek, materi, bahasa, penyajian, dan kegrafikan. Namun, diperlukan beberapa perbaikan sesuai saran dari setiap ahli melalui revisi modul pertama.

Tabel 1 Hasil Validasi Modul

\begin{tabular}{ccl}
\hline Aspek & $\begin{array}{c}\text { Persentase } \\
(\%)\end{array}$ & Kategori \\
\hline Materi & 85,9 & Sangat baik \\
\hline Penyajian & 85,8 & Sangat baik \\
\hline Bahasa & 85,4 & Sangat baik \\
\hline Kegrafisan & 86,3 & Sangat baik \\
\hline
\end{tabular}

Hasil validasi RPP adalah 78,2\% dengan kategori baik yang meliputi perumusan tujuan, pengorganisasian materi, pemilihan sumber belajar dan media ajar, model dan metode pembelajaran, dan penilaian hasil. Sedangkan untuk soal kognitif $72,7 \%$ yang menunjukan kategori baik meliputi materi, penyajian soal, penskoran, dimensi pengetahuan, serta dimensi proses kognitif soal. Sedangkan berdasarkan hasil uji validitas soal menggunakan rumus korelasi point biserial Arikunto (2006:281) diketahui bahwa terdapat 5 soal yang tidak valid dari 20 soal, sehingga 5 soal tersebut tidak dipakai. Hasil uji reliabilitas menunjukan bahwa nilai $r$ adalah 0,861 dapat diartikan interprestasi soal dalam katagori tinggi. Reliabilitas berhubungan dengan masalah kepercayaan. Menurut Suharsimi Arikunto (2010:221), suatu tes dapat dikatakan mempunyai taraf kepercayaan yang tinggi apabila tes tersebut memberikan hasil yang tetap

Hasil penilaian guru dan siswa pada uji skala kecil, penilaiannya meliputi aspek materi, bahasa dan media. Hasilnya menunjukkan bahwa modul tersebut termasuk kategori baik menurut rata-rata guru dan siswa. Namun, perlu adanya perbaikan sesuai saran yang diperoleh melalui revisi modul uji coba awal. Revisi modul uji skala kecil yang dilakukan meliputi: a) Memperhatian besar kecilnya huruf pada judul bab, b) membetulkan kata-kata yang salah ketik, c) penempatan gambar dirapikan.

Hasil penilaian guru dan siswa pada uji coba lapangan dan uji pelaksanaan lapangan menunjukkan bahwa penilaian modul pada aspek materi, bahasa dan media menunjukkan bahwa modul tersebut termasuk kategori sangat baik menurut rata-rata guru dan siswa. Namun perlu adanya perbaikan sesuai saran yang diperoleh melalui revisi modul uji coba lapangan. 
Adapun revisi meliputi; a) Gambar yang kecil pada materi ikatan ion agar diperbesar agar lebih jelas; b) Kata-kata kunci agar di pertebal (bold); c) Sampulnya dicetak jagan diprint agar lebih menarik.

\section{Efektifitas Modul kimia berbasis SETS terintegrasi Nilai Islam pada Materi Ikatan Kimia.}

Hasil analisis pembelajaran ranah kognitif diperoleh dari pretes (tes awal) kelas kontrol dan kelas pengguna produk tampak kedua kelas menunjukkan kondisi yang sama. Hal ini juga diperkuat dengan uji t yang menyatakan nilai kedua kelas sama. Sedangkan jika dilihat dari hasil postes (tes akhir) menunjukkan kelas kontrol siswa yang tuntas sesuai kriteria ketuntasan minimal (75) hanya $10 \%$ dan kelas pengguna produk siswa yang tuntas mencapai 55\%. Hal ini menunjukkan ada perbedaan hasil belajar yang dicapai antara kelas kontrol dengan kelas pengguna produk. Hal ini diperkuat dengan hasil analis uji hipotesis yang menggunakan uji statistik parametrik dimana menghasilkan $(\mathrm{Sig}<0,05)$ dimana $\mathrm{HO}$ diterima, dapat disimpulkan adanya perbedaan signifikan antara kelas kontrol dengan kelas modul SETS terintegrasi nilai islam. Hal ini sejalan dengan Handayani (2013) dan Muzari (2015) menyatakan bahwa pendekatan salingtemas (SETS) berpengaruh positif terhadap hasil belajar kognitif siswa.

Tabel 2 Rangkuman Hasil Belajar Siswa

\begin{tabular}{ccccc}
\hline Aspek & \multicolumn{2}{c}{$\begin{array}{c}\text { Kelas } \\
\text { kontrol }\end{array}$} & Kelas eksperimen \\
\cline { 2 - 5 } & Pretes & Posttes & Pretes & Posttes \\
\hline $\begin{array}{c}\text { Nilai } \\
\text { tertinggi }\end{array}$ & 40 & 83 & 40 & 93 \\
\hline $\begin{array}{c}\text { Nilai } \\
\text { terendah }\end{array}$ & 13 & 40 & 20 & 60 \\
\hline Rata-rata & 22,45 & 57,25 & 24,80 & 77,20 \\
\hline
\end{tabular}

Pada Uji Efektivitas Penilaian Sikap, Data diambil saat kegitan belajar berlangsung, berdasarkan hasil analisis data terhadap kelas eksperimen dan kelas kontrol diperoleh rata-rata nilai kelas pada setiap pertemuan. Data kelas eksperimen menunjukkan nilai yang lebih tinggi dibandingkan nilai pada kelas kontrol yaitu pertemuan I $(3,46)$, pertemuan II $(3,35)$, dan pertemuan III $(3,38)$. Selain data tersebut jika dilihat dari persentase rata-rata nilai kelas, nilai kelas eksperimen juga lebih besar yaitu $85 \%$ sedangkan nilai kelas kontrol $77,64 \%$. Hal ini juga dikuatkan dengan hasil analis uji t menghasilkan $t$ hitung $(5,645)>t$ tabel $(2,02)$ dan $p$-value Sig (2-tailed) $<0,05$ sehingga H0 ditolak dan dapat disimpulkan ada perbedaan signifikan nilai sikap kelas kontrol dan kelas eksperimen. Peningkatan nilai sikap ini juga terjadi pada penelitian Imaduddin (2013) yang memadukan quantum learning dan salingtemas.

Penilaian psikomotorik pada penelitian ini mencakup empat penilaian yaitu 1) Mengamati fenomena pencemaran oleh sulfur dioksida; 2) Melakukan Percobaan uji kepolaran senyawa; 3) Menyajikan laporan tertulis praktikum; 4) Mempresentasikan hasil diskusi kelompok. Berdasarkan data tersebut ketahui nilai rata- rata prosentase kelas eksperimen $(84,38)$ lebih besar dibandingkan nilai kelas kontrol $(75,31)$. Hasil ini kemudian diperkuat dengan analisis statistik uji $\mathrm{t}$ yang menghasilkan $t$ hitung $(3,65)>t$ tabel $(2,02)$ dan $p$-value Sig (2-tailed) $<0,05$ sehingga H0 ditolak dan dapat disimpulkan ada perbedaan signifikan nilai psikomotor kelas kontrol dan kelas eksperimen. Hal ini sejalan dengan hasil penelitian Nuryanto (2010) dan Mukhlis (2011) bahwasanya pendekatan SETS selain meningkatkan hasil belajar kognitif siswa juga dapat meningkatkan minat dan keaktifan belajar siswa.

Gambar 1 Grafik Hasil Nilai Sikap

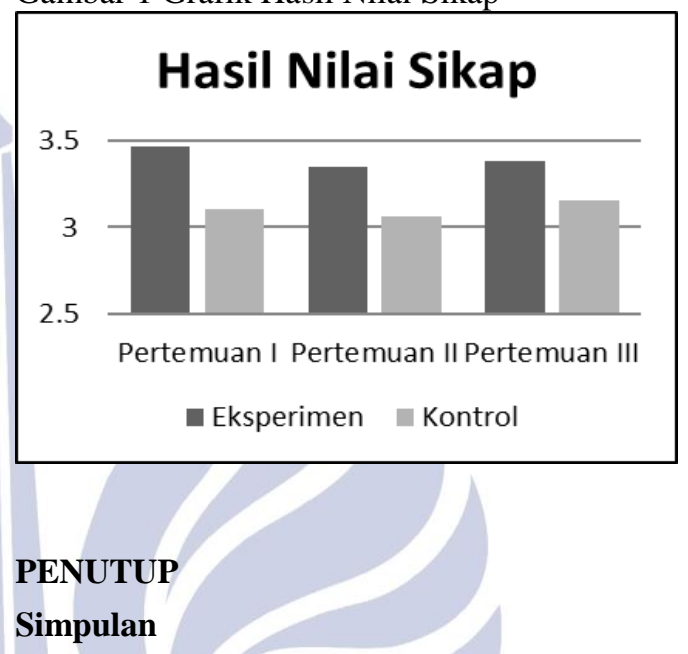

Berdasarkan analisis yang telah dipaparkan pada bab sebelumnya, maka dapat disimpulkan sebagai berikut: Pertama, Pengembangan modul kimia berbasis SETS terintegrasi nilai islam dilakukan dengan menggunakan langkah pengembangan yang kemukakan oleh Borg \& Gall (1983) sampai pada tahap ke sembilan.

Kedua, Pengembangan modul kimia berbasis inkuiri terbimbing yang disertai ayat-ayat Al-Qur'an dan Hadits dapat dikatakan "sangat baik" ditinjau dari aspek materi $85,9 \%$, penyajian $85,8 \%$, bahasa $85,4 \%$ dan kegrafisan $86,03 \%$. Persentase tersebut didapatkan berdasarkan penilaian dari para validator, sehingga dapat disimpulkan bahwa modul yang dikembangkan dikatakan "sangat baik"untuk digunakan dalam pembelajaran kimia.

Ketiga, Pengembangan modul kimia berbasis SETS terintegrasi nilai islam yang dikembangkan efektif digunakan untuk meningkatkan hasil belajar para siswa. Hal tersebut dilihat dari hasil uji efektifitas sebesar 0,000 yang mana lebih rendah dari taraf signifikasi $\alpha=0,05$ sehingga dapat disimpulkan bahwa hasil belajar menggunakan modul kimia berbasis SETS terintegrasi nilai islam lebih baik dari pembelajaran konvensional.

\section{Saran}

Bagi Guru, hendaknya memahami metode SETS pada modul yang akan digunakan dalam proses pembelajaran. Bagi peneliti selanjutnya, agar lebih memperbanyak contoh-contoh keterkaitan antara materi ikatan kimia dengan nilai islam. Selain itu, peneliti selanjutnya diharapkan agar mengembangkan materi- 
materi lain yang masih berhubung kait dengan ayat-ayat Al-Qur'an dan hadits.

Terakhir, bagi siswa. Hendaknya para siswa tidak menggantungkan guru sebagai pusat pembelajaran di kelas. Selain itu, siswa diharapkan menggali lebih dalam materi-materi yang sedang dipelajari. Terutama berusaha mekaitkan dengan ayat-ayat Al-Qur'an dan hadits sehingga menjadi nilai (perilaku) yang dapat diterapkan dalam kehidupan sehari-hari.

\section{DAFTAR PUSTAKA}

Aiken, L.R. 1985. Three Coefficients for Analyzing the Reliability and Validity of Ratings. Educational and Psychological Measurement, 45: 131-142.

Arikunto, S. 2006, Prosedur Penelitian: Suatu Pendekatan Praktek, Edisi Revisi, PT, Rineka Cipta, Jakarta.

Binadja, A. 2005. Pedoman Pengembangan Bahan Pemblajaran Bervisi dan Berpendekatan SETS (Science, Environment, Technology and Society) atau (Sains,Lingkungan, Teknologi dan Masyarakat). Laboratorium SETS : Program Pascasarjana UNNES

Depdiknas. 2008. Teknik Penyusunan Modul. Jakarta: Direktorat Jenderal Manajemen Pendidikan Dasar dan Menengah, Departemen Pendidikan Nasional.

Hamid, D. 2011. Metode Penelitian Pendidikan. Bandung: Alfabeta.

Hamidi F., Bagherzadeh Z., Gafarzadeh S. 2010. The Role of Islamic Education in Mental Health. Social and Behavioral Sciences. 5 : 1991-1996

Handayani, D. 2013. Pengembangan Modul IPA Terpadu Berbasis SETS Dengan Penekanan Berpikir Kritis Pada Tema Bahan Kimia Pada Makanan. UNS: Surakarta

Imaduddin M. 2013. Modul Q-SETS sebagai Rekayasa Bahan Ajar Kimia yang Bermuatan Quantum Learning dan Bervisi Salingtemas. Jurnal Pendidikan Sains Universitas Muhammadiyah Semarang. (1) 1: 26-36

Ismail M. 2013. Educational Strategies to Develop Discipline Among Students from the Islamic Perspectives. Evaluation of Learning for Performance Improvement International Conference. Social and Behavioral Sciences. 107 : 80-87

Kartanegara, M. 2006. Reaktualisasi Tradisi Ilmiah Islam. Jakarta: Penerbit Baitul Ihsan

Mukhlis Rohmad. 2011. Pembelajaran Dengan Pendekatan Cep (Chemo-Entrepreneurship) Yang Bervisi SETS (Sceince, Environment, Technology and Society) Guna Meningkatkan Kualitas Pembelajaran. Pendidikan Sains Pps Uns.
Muzari, I. 2015. Pengembangan Modul IPA Terpadu Berbasis SETS pada Tema Makanan Sehat dan Tubuhku untuk Meningkatkan Hasil Belajar. UNS: Surakarta

Nugraha, D.A. 2013. Pengembangan Bahan Ajar Reaksi Redoks Bervisi SETS, Berorientasi Konstruktivis. Journal of Innovative Science Education. JISE 2 (1).

Nuryanto \& Binadja, A. 2010. Efektivitas Pembelajaran Kimia dengan Pendekatan Salingtemas Ditinjau dari Minat dan Hasil Belajar Siswa. Jurnal Inovasi Pendidikan Kimia

Prastowo, A. 2012.Panduan Kreatif Membuat Bahan Ajar Inovatif. Yogyakarta: Diva Press.

Pritchard, A. and Woollard, J. 2010. Psychology for the Classroom: Constructivism and Social Learning. New York: Routledge.

Rahman, A., Kasim D., 2014. Pendidikan Karakter Berbasis Al-Qur'an: Upaya Menciptakan Bangsa yang Berkarakter. Al-Ulum. Volume. 14 Nomor 1, Hal 247-268.

Roqib, Moh. 2011. Prophetic Education. Purwokerto: STAIN Press

Rohmadi, M,. 2013. Pembelajaran I-SETS (Studi Pada Pembelajaran Kimia Dasar Program Studi Tadris Biologi STAIN Palangka Raya Tahun Akademik 2012/2013). Edu Sains, Volume 1, Nomor 1

Rokhmana F., Syafudin A., Yuliati. 2013. Character Education For Golden Generation 2045 (National Character Building for Indonesian Golden Years). Social and Behavioral Sciences. 14 : 1161 - 1165

Saputro, C.N.A., 2008. Pengintegrasian Nilai-nilai Religius dalam Buku Pelajaran Kimia SMA/MA untuk Membentuk Karakter Insan Mulia pada Siswa. Surakarta: UNS

Suparman, A., 1997. Desain Instruktural. Jakarta : Rineka Cipta

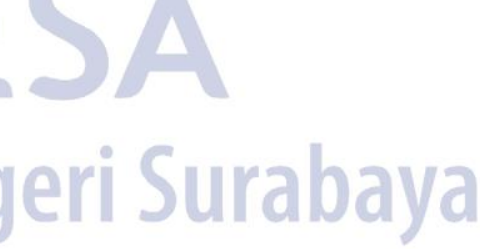

